\title{
HA1077 inhibits cell proliferation of oral squamous cell carcinoma in vitro
}

\author{
HA1077 inibe a proliferação celular em carcinoma de células escamosas oral in vitro \\ HA1077 inhibe la proliferación celular en el carcinoma oral de células escamosas in vitro
}

Received: 02/08/2022 | Reviewed: 02/16/2022 | Accept: 02/17/2022 | Published: 02/26/2022

Guilherme Henrique Borges

ORCID: https://orcid.org/0000-0003-4086-0534 Federal University of Triângulo Mineiro, Brazil E-mail: Guido@live.com

Simone de Sales Costa Moreira Carboni ORCID: https://orcid.org/0000-0003-1329-7504 Federal University of Triângulo Mineiro, Brazil E-mail: simonemorecarboni@gmail.com Anna Cecília Dias Maciel Carneiro ORCID: https://orcid.org/0000-0003-4865-1286 Federal University of Triângulo Mineiro, Brazil E-mail: annaceciliamaciel@gmail.com

Lorraine Stephanie Hiss

ORCID: https://orcid.org/0000-0003-3872-287X Federal University of Triângulo Mineiro, Brazil E-mail: Lorraine_Hiss@hotmail.com

Isadora Caixeta da Silveira ORCID: https://orcid.org/0000-0002-7723-2059 Federal University of Triângulo Mineiro, Brazil E-mail: isadora-biomed@hotmail.com

Virgínia Oliveira Crema

ORCID: https://orcid.org/0000-0001-5219-532X Federal University of Triângulo Mineiro, Brazil E-mail: virginia.crema@uftm.edu.br

\begin{abstract}
Oral squamous cell carcinoma is a common malignant lesion. ROCKs proteins are associated with pathogenesis and progression of human tumours. This study aimed to evaluate the functional role of ROCKs in the regulation of cell proliferation of oral squamous cell carcinoma in vitro. BrdU incorporation assays and KI-67 immunoexpression were performed by using SCC-4 cell line from oral squamous cell carcinoma. Control and treated cells: HA-1077 (25, 50 and $100 \mu \mathrm{mol} / \mathrm{l}), 50 \mu \mathrm{mol} \mathrm{HA}-1077$ and Y-27632 $30 \mu \mathrm{mol} / 1$, Y-27632 $30 \mu \mathrm{mol} / 1$ were cutured for $6 \mathrm{~h}$. The number of SCC-4 cells treated with: HA-1077 $(25,50$ and $100 \mu \mathrm{mol} / \mathrm{l})$, HA-1077 $50 \mu \mathrm{mol} / \mathrm{l}$ and/or Y-27632 $30 \mu \mathrm{mol} / \mathrm{l}$ was significantly lower than control cells in BrdU assay $[\mathrm{F}(5.17)=443.818, \mathrm{p}<0.0001]$ and in KI-67 assay $[\mathrm{F}=192.595$, d.f. $=5,17 ; \mathrm{p}<0.0001]$. The results obtained suggest that the pathways that evolve ROCKs proteins play an important functional role in the positive regulation of cell proliferation in oral squamous cell carcinoma.
\end{abstract}

Keywords: Cell proliferation; HA-1077; Oral squamous cell carcinoma; ROCKs; SCC-4; Y-27632.

\section{Resumo}

Uma forma de tentar controlar o carcinoma de células escamosas oral é investir em novas terapias voltadas para a biologia molecular dos receptores e suas vias de sinalização intracelular. Este estudo teve como objetivo avaliar o efeito do LY2109761 (um inibidor dos receptores TGF- $\beta$ ) na migração celular no carcinoma epidermóide oral in vitro. Citoesqueleto de actina de controle de células SCC-4 e LY2109761 (1, 5 e $10 \mu \mathrm{M})$ tratado em Matrigel tridimensional foram analisados usando microscopia confocal a laser. Controle e células tratadas com LY2109761 $(1,5$ e $10 \mu \mathrm{M})$ que migraram através da membrana de ensaios de migração de células tridimensionais foram contadas, a significância foi $\mathrm{p}<0,05$. Células controle foram observadas com citoplasma volumoso, córtex celular preservado e citoesqueleto de actina bem desenvolvido com filamentos de actina bem distribuídos. Independentemente da concentração, as células tratadas apresentaram: morfologia arredondada e tamanho pequeno, citoplasma escasso, F-actina cortical menos clara que as células de controle e rompimento dos filamentos de actina. As células migratórias foram inibidas pelo tratamento com LY2109761 $[\mathrm{F}(3,11)=3742, \mathrm{p}<0,0001]$, de uma forma dependente da dose. Esses resultados sugerem que o LY2109761 exerce um efeito inibitório sobre o citoesqueleto de actina e a migração celular nas células SCC-4, portanto, é uma opção terapêutica promissora para o carcinoma de células escamosas oral.

Palavras-chave: Proliferação celular; HA-1077; Carcinoma de células escamosas oral; ROCKs; SCC-4; Y-27632. 


\section{Resumen}

El carcinoma oral de células escamosas es una lesión maligna común. Las proteínas ROCKs están asociadas con la patogénesis y progresión de tumores humanos. Este estudio tuvo como objetivo evaluar el papel funcional de las ROCK en la regulación de la proliferación celular del carcinoma oral de células escamosas in vitro. Los ensayos de incorporación de BrdU y la inmunoexpresión de KI-67 se realizaron utilizando la línea celular SCC-4 de carcinoma de células escamosas orales. Células control y tratadas: HA-1077 (25, 50 y $100 \mu$ mol/1), $50 \mu$ mol HA-1077 y Y-27632 30 $\mu \mathrm{mol} / 1, \mathrm{Y}-2763230 \mu \mathrm{mol} / 1$ se cultivaron durante $6 \mathrm{~h}$. El número de células SCC-4 tratadas con: HA-1077 (25, $50 \mathrm{y}$ $100 \mu \mathrm{mol} / \mathrm{l}), \mathrm{HA}-107750 \mu \mathrm{mol} / 1 \mathrm{y} / \mathrm{o} \mathrm{Y}-2763230 \mu \mathrm{mol} / \mathrm{l}$ fue significativamente menor que las células de control en el ensayo $\operatorname{BrdU}[\mathrm{F}(5,17)=443.818$, p<0,0001] y en ensayo KI-67 $[\mathrm{F}=192.595$, df = 5,17; p<0,0001]. Los resultados obtenidos sugieren que las vías que evolucionan las proteínas ROCKs juegan un papel funcional importante en la regulación positiva de la proliferación celular en el carcinoma de células escamosas oral.

Palabras clave: Proliferación celular; HA-1077; Carcinoma oral de células escamosas; ROCKs; SCC-4; Y-27632.

\section{Introduction}

Despite the improvement in the diagnosis of head and neck cancer and the large number of research and advances in oncology, morbidity and mortality rates remain high, representing the sixth most common cancer worldwide (Massano et al., 2006). Oral squamous cell carcinoma (OSCC) accounts for 90\% of cases (Travassos et al., 2017) and the risk factors associated with its development are: smoking, alcoholism and HPV infection (Ragin et al., 2016). The association between alcohol and tobacco due to its synergistic effect multiplies the chances of developing the disease (Lin et al., 2016).

Tumour growth occurs by cell proliferation and differentiation, also there are the presence of a subpopulation of cells that exhibit self-renewal capacity, called, cancer stem cells (Chiou et al., 2008). Therefore, it is necessary to identify proteins that regulate the proliferation of OSCC cells and thus enable the development of a specific therapy capable of effectively blocking this signal transduction pathway (Wei et al., 2016). The occurrence of metastases is common and aggravates the prognosis of the disease, being the main cause of the deaths (Stucky et al., 2017).

Previously, Rho-kinase (ROCKs) were identified as important for the regulation of OSCC cell motility (Moreira Carboni et al., 2015). The ROCKs belong to the AGC family (protein G-linked kinases), being the most well-characterized effectors of Rho proteins, and exert their function through the phosphorylation of a specific substrate, when bound to the active form of Rho protein (Amano et al., 2010). The overexpression of ROCKs is involved with the appearance of various diseases and tumour progression (Bora \& Shrivastava, 2017) thus, the Rho/ROCK pathway is a good molecular target for anticancer therapy (Abe et al., 2014).

To study the functional role of ROCKs proteins, the following inhibitors may be used: HA-1077, 1- (5Isoquinolinylsulfonyl) homopiperazine dihydrochloride, Fasudil dihydrochloride, which competes with the same ATP binding site (Amano et al., 2010); and Y-27632, (R)-(+)-trans-4-(1-Aminoethyl)-N-(4-Pyridyl) cyclohexanecarboxamide dihydrochloride, which acts with an ATP binding enzyme (Ishizaki et al., 2000).

This study aimed to evaluate the functional role of ROCKs in regulation of cell proliferation in SCC-4 cells from OSCC in vitro, using its specific inhibitors HA-1077 and/or Y-27632. Evaluation of the cell proliferation rate was performed by BrdU incorporation assays and immunohistochemistry for KI-67 (proliferative cell marker).

\section{Methodology}

This is a experimental, prospective, quantitative and analytical study (Pereira et al, 2018).

SCC-4 cell line from OSCC of human tonguel from the American Type Culture Collection - ATCC@, obtained through the Rio de Janeiro Cell Bank (BCRJ). SCC-4 cells were cultured in Dulbecco's modified Eagle's medium/F12 (DMEM/F12) containing 10\% fetal bovine serum (FBS), $100 \mathrm{U} / \mathrm{ml}$ penicillin, $100 \mu \mathrm{g} / \mathrm{ml}$ streptomycin and $400 \mathrm{ng} / \mathrm{ml}$ hydrocortisone in a humid incubator with $5 \% \mathrm{CO} 2$ atmosphere $/ 95 \%$ air at $37^{\circ} \mathrm{C}$. After the cells reached semi-confluence, the 
experiments were performed.

\section{Cell proliferation assays}

The BrdU incorporation and KI-67 immunoexpression experiments for analysis of the effect of HA-1077 and Y27632 on the rate of cell proliferation in OSCC were performed in biological triplicates and experimental duplicates. 1x104 SCC-4 cells were seeded in six-well plates containing glass coverslips and cultured for $24 \mathrm{~h}$. For the BrdU incorporation assay, the medium was changed from the control cells and three concentrations of HA-1077 (Sigma-Aldrich, St. Louis, MO, USA) 25, 50 and $100 \mu \mathrm{mol} / \mathrm{l}$; HA-1077 $50 \mu \mathrm{mol} / 1$ associated with Y-27632 (Calbiochem, San Diego, CA, USA) $30 \mu \mathrm{mol} / 1$; and Y$2763230 \mu \mathrm{mol} / 1$ were added to the medium of the treated cells. Also $0.5 \mu \mathrm{g} / \mathrm{ml} \mathrm{BrdU}$ (Sigma-Aldrich, St. Louis, MO, USA) was added to all wells. Control and treated cells were incubated for $6 \mathrm{~h}$. For the KI-67 immunoexpression assay, only medium was added to wells with control cells. In the wells with treated cells, the treatments were: HA-1077 in three concentrations 25, 50 and $100 \mu \mathrm{mol} / \mathrm{l}$; HA-1077 $50 \mu \mathrm{mol} / \mathrm{l}$ associated with Y-27632 $30 \mu \mathrm{mol} / \mathrm{l}$, and Y-27632 $30 \mu \mathrm{mol} / \mathrm{l}$. All samples were incubated for $6 \mathrm{~h}$.

\section{Immunocytochemical reactions}

After the treatment period, the cells were washed twice for 5 min with Dulbecco's Phosphate Buffered Saline (D-PBS) with calcium and magnesium and then fixation was done with $4 \%$ paraformaldehyde for $1 \mathrm{~h}$. In the BrdU incorporation assay, cells were washed twice for 5 min with D-PBS and incubated with $1 \mathrm{~N} \mathrm{HCl}$ for $1 \mathrm{~h}$ at $37^{\circ} \mathrm{C}$. After washing with D-PBS, permeabilization was performed with $0.2 \%$ Triton X-100 for 5 min. Blocking of non-specific sites was done with $3 \%$ DPBS/BSA for 20 min. Incubation with BrdU primary antibody (Vector Laboratories, Burlingame, CA, USA) and against KI67 (MIB-1, sc-101861, Santa Cruz Biotechnology Inc., Santa Cruz, CA), diluted 1:50 in D-PBS/0.1\% BSA was performed for $16 \mathrm{~h}$ in a humid chamber at room temperature. After washing with D-PBS for 10min, the samples were incubated with Alexa 488 (Molecular Probes, Eugene, OR, USA) labeled secondary antibody, 1:1000 in 0.1\% DPBS / BSA for $2 \mathrm{~h}$ in a room temperature and dark chamber. After washing twice with D-PBS for 10min, the disclosure of nuclei was done with DAPI (Sigma-Aldrich, St. Louis, MO, USA) 1:500. The slides were mounted with glycerol-carbonate.

\section{Morphometry and statistical analysis}

Control cells and treated cells were evaluated in ten random fields under fluorescence microscopy. The nuclei of all the cells labeled with DAPI (100\%) and the BrdU or KI-67 positive cells were quantified. The percentage of BrdU and KI-67 positive cells were calculated.

The results were analyzed with SPSS $16.0 ®$ program and graphs made with Graphpad Prism®. The distribution was analyzed using the Levene variance test. Parametric tests were used: analysis of variance (ANOVA) and Tukey's post-test. Differences were considered significant when $\mathrm{P}<0.05$.

\section{Results}

\section{Effect of inhibition of ROCKs proteins with HA-1077 and/or Y-27632 on SCC-4 cell proliferation}

Treatment with HA-1077 and / or Y-27632 inhibited the proliferation rate of SCC-4 cells $[\mathrm{F}=443.818$, d.f. $=5,17$; $\mathrm{p}<0.0001]$ at the concentrations studied. When compared with the number of control cells $(49.22 \pm 1.68$ cells $)$ which have incorporated BrdU (proliferative), the number of proliferating cells was significantly less in the samples treated with HA-1077 at concentrations: $25 \mu \mathrm{mol} / 1(32.07 \pm 1.76$ cells, $\mathrm{p}<0.0001), 50 \mu \mathrm{mol} / 1(23.02 \pm 1.07$ cells, $\mathrm{p}<0.0001)$ and $100 \mu \mathrm{mol} / 1(13.07 \pm 0.75$ cells, $\mathrm{p}<0.0001)$. Also, it was significantly lower than the control, the number of proliferating cells treated with HA-1077 50 
$\mu \mathrm{mol} / 1$ associated with $\mathrm{Y}-2763230 \mu \mathrm{mol} / 1(12.73 \pm 1.07$ cells, $\mathrm{p}<0.0001)$ and, with $\mathrm{Y}-2763230 \mu \mathrm{mol} / 1(11.80 \pm 0.18$ cells, $\mathrm{p}<0.0001$ ), (Figure 1A).

Immunoexpression of KI-67 (cell proliferation marker) in control and treated SCC-4 cells HA-1077 and / or Y-27632 demonstrated similar results to those observed by BrdU incorporation assay. Treatment with HA-1077 and/or Y-27632 inhibited the proliferation rate of SCC-4 cells $[F=192.595$, d.f. $=5,17 ; \mathrm{p}<0.0001]$ at the concentrations studied. When compared to the number of control cells $(35.01 \pm 1.67$ cells), the number of proliferating cells was significantly lower in the samples treated with HA-1077 at concentrations: $25 \mu \mathrm{mol} / 1$ (20.76 \pm 0.70 cells, $\mathrm{p}<0.0001), 50 \mu \mathrm{mol} / 1(19.04 \pm 0.42$ cells, $\mathrm{p}<0.0001)$ and $100 \mu \mathrm{mol} / 1(13.46 \pm 0.49$ cells, $\mathrm{p}<0.0001)$. Also, it was significantly lower than the control, the number of proliferating cells treated with HA-1077 $50 \mu \mathrm{mol} / \mathrm{l}$ associated with Y-27632 $30 \mu \mathrm{mol} / 1(16.81 \pm 0.98$ cells, $\mathrm{p}<0.0001)$ and with Y-27632 $30 \mu \mathrm{mol} / \mathrm{l}(12.64 \pm 1.23$ cells, $\mathrm{p}<0.0001)$ (Figura 1B).

Figure 1. Functional role of ROCKs on the cell proliferation of oral squamous cell carcinoma, in vitro. Percentage of proliferative SCC-4 cells after 6 hours. Control cells and treated cells for 6 h: HA-1077 25, 50, $100 \mu$ mol/l, HA-1077 50 $\mu \mathrm{mol} / \mathrm{l}$ and $\mathrm{Y}-2763230 \mu \mathrm{mol} / \mathrm{l}$ and $\mathrm{Y}-2763230 \mu \mathrm{mol} / \mathrm{l}$. (A) BrdU assay and (B) KI-67 immunoexpression assay. *p<0,05, $* * \mathrm{p}<0,001 \mathrm{e} * * * \mathrm{p}<0,0001$.
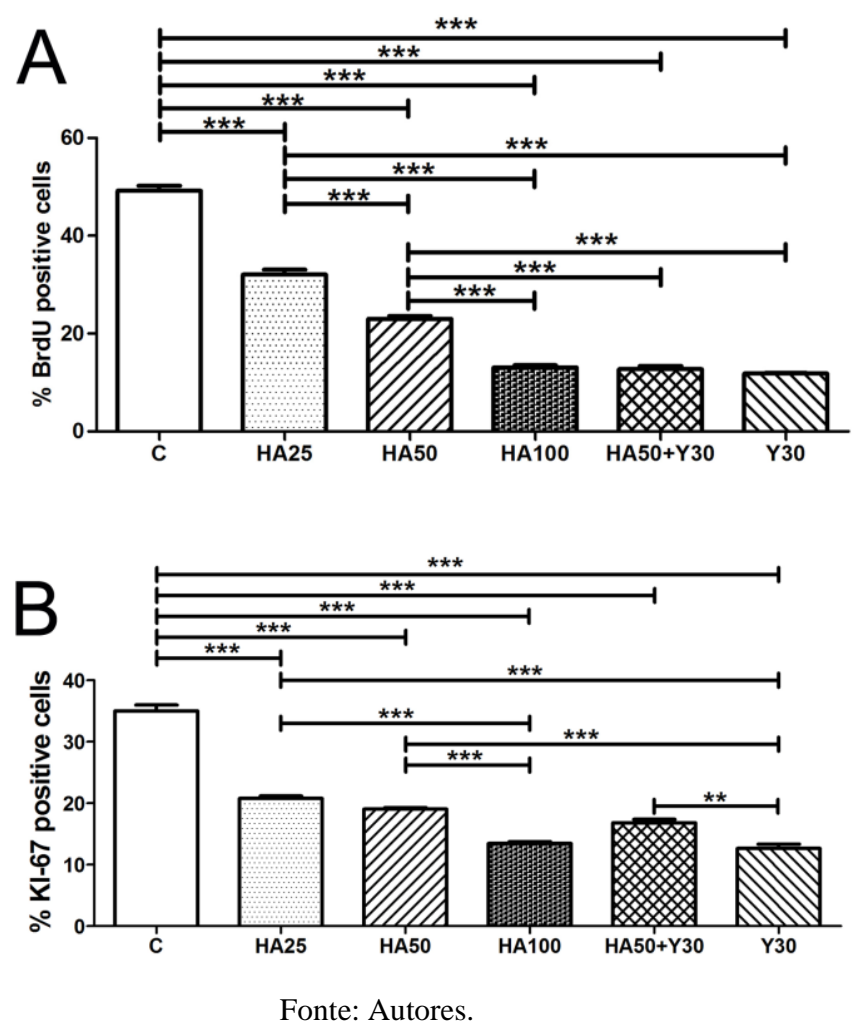

\section{Discussion}

This study demonstrated that ROCKs proteins play an important functional role on the proliferation of SCC-4 cells obtained from OSCC. Deregulation of signaling pathways that control the cell proliferation is a key event for the initiate and progression of cancer (Evan \& Vousden, 2001). Cell division is an extremely coordinated and controlled process, consisting of two preparatory phases, G1 and G2, and two functional phases, S and M. In G1 occurs the biochemical preparation of the cell for the S phase, which is characterized by DNA synthesis, and in G2 there is the synthesis of the components for the M phase, in which mitosis occurs (Coleman et al., 2004). 
For the occurrence of tumourigenesis, it is required that occur mutations and epigenetic changes that alter the cell proliferation and survival (Gómez del Pulgar et al., 2005). One of the main causes of death in cancer patients is the metastasis, which is characterized by the movement of tumour cells from one primary site to the formation of a secondary site, where the growth of another tumour mass (Steeg, 2016). During this process, tumour cells acquire some abilities, such as: selfsufficiency in growth signals, insensitivity to anti-growth signals, unlimited doubling potential, apoptosis evading ability, and uncontrolled proliferation (Bora \& Shrivastava, 2017). This behaviour is regulated by the binding of extracellular molecules to receptors located in the cell membrane, which results in the activation of one or more intracellular signaling pathways and effector proteins (Demoulin \& Essaghir, 2014). In this way, the molecular pathways of the cells are a therapeutic target in the treatment of malignancies (Glazer et al., 2009).

In this study, two inhibitors of ROCKs, HA-1077 and Y-27632, were used to evaluate the functional role of these proteins in the regulation of proliferation in SCC-4 cells from OSCC. The drugs used in cancer treatment should prevent the establishment of metastasis and reduce the size of existing tumours, in this manner, cell cycle progression control is an effective strategy for inhibiting tumour growth and the appearance of metastases (Steeg, 2016). In Japan HA-1077 has been approved since 1995 for use in the treatment of vasospasm after subarachnoid haemorrhage (Defert \& Boland, 2017). Y-27632 due to its inhibitory action on ROCKs has been considered a potential therapeutic agent (Breitenlechner et al., 2003). Both ROCK inhibitors have good permeability and are able to cross the cell membrane and compete for the ATP binding site in the ROCKs, inhibiting the activities of ROCK1 and ROCK2 (Johan \& Samuel, 2019).

The two isoforms of ROCKs, ROCK1 and ROCK2, regulate various cellular processes, including cell proliferation (Wei et al., 2016). Blockade of ROCK1 or ROCK2 had no effect on tumourigenesis of lung cancer and melanoma in mice, however, blockade of both ROCKs prevented tumour formation (Kümper et al., 2016). In agreement with these results, in this study the inhibitors HA-1077 and Y-27632, which inhibit both isoforms of ROCKs, led to the decrease of the proliferation rate of SCC-4 cells of OSCC, demonstrated the importance of these proteins for the regulation of this biological process. Also ROCKs regulate positively cell proliferation in others tumour cells (Wei et al., 2016).

In other sites, ROCK1 expression was correlated with tumour size and lymph node metastasis, while ROCK2 expression was associated only with the tumour size in squamous cell carcinoma of the larynx human (Zhang et al., 2015). While ROCK1 was overexpressed in malignant vascular tumours, ROCK2 was overexpressed in benign and malignant vascular tumours. In addition, in vascular tumours the decreased activation of ROCK2 resulted in a reduction in the size and rate of tumour proliferation (Amaya et al., 2017). Although in this study the quantification of the expression of ROCK1 and ROCK2 proteins was not possible, ROCK2 is probably the isoform responsible for the regulation of proliferation in OSCC cells.

Rho GTPases also contribute to the separation of daughter cells by contraction of the actinomyosin ring (David et al., 2012), also participate in the regulation of physiological and pathological processes (Vega \& Ridley, 2008). In the proliferation of tumour cells, the ROCKs activate oncogenes, contraction of the actinomyosin cytoskeleton, cell adhesion and cytokinesis (Wei et al., 2016). Thus, ROCKs are attractive targets for the treatment of neoplasms, and in this study it was observed that the inhibition of ROCKs leads to a decrease in the proliferation rate of SCC-4 cells.

The results obtained in this study suggest that signal transduction pathways involving ROCKs play a very important role in the regulation of tumour growth. Their Rho upstream proteins (RhoA, RhoB and RhoC) are hardly mutated, however overexpression of these proteins occurs in human tumours (Gómez del Pulgar et al., 2005). While RhoA and RhoC have increased expression in human tumours and are oncogenic, RhoB has decreased levels during tumour progression and its expression is inversely related to tumour aggressiveness (Vega \& Ridley, 2008).

In squamous cell carcinoma of the head and neck an increased expression of RhoA (Abraham et al., 2001) and RhoC 
(Kleer et al., 2006) has already been reported. RhoA is involved in practically every stage of cancer progression (Vega \& Ridley, 2008). In SCC-4 cells of OSCC, inhibition of RhoA expression resulted in expansion of cell doubling time and reducing cell proliferation. The silencing of RhoC in breast cancer cell lines (Xu et al., 2017) and the reduced expression of RhoC in endometrial adenocarcinoma cells (Liu et al., 2016) have led to increased apoptosis and inhibition of cell proliferation and invasion.

The involvement of ROCKs in the positive regulation of cell proliferation of SCC-4 cells from OSCC was evaluated by treatment with two specific inhibitors of these proteins: HA-1077 and Y-27632. In SCC-4 cells, inhibition of ROCKs with HA-1077 and/or Y-27632 has resulted in morphological changes and disorganization of the actin cytoskeleton, and HA-1077 led to reduced process migration and cell invasion (Moreira Carboni et al., 2015). Also in Tca8113 and CAL-27 cells from OSCC of tongue, treatment with Y-27632 caused inhibition of growth, invasion and migration (Wang et al., 2016). Similar results were found in other cancers. HA-1077 treatment inhibits the growth and development of metastasis in culture of NCIH446 cells from lung cancer (Yang et al., 2012). Y-27632 treatment significantly decreases cell proliferation in a concentration-dependent manner and time in culture of T24 and 5637 bladder cancer cells (Jiang et al., 2015), also it inhibits significantly cell proliferation, migration and invasion in OSCC of human larynx (Zhang et al., 2015).

In this study, two methodologies were used to evaluate OSCC cell proliferation, BrdU incorporation assay and KI-67 immunoexpression. Through the BrdU incorporation assay, it was demonstrated that in the RCC4 cell line of clear cell renal carcinoma, treatment with Y-27632 was cytotoxic and cytostatic (Thompson et al., 2017). In hemangioma-derived endothelial cells, after treatment with Y-27632 a significant decrease in KI-67 antigen expression occurs (Qiu et al., 2017). In mice with gastric cancer, treatment with HA-1077 reduced the amount of cells expressing the cell proliferation marker KI-67, inhibiting ROCKs reduced the growth of gastric cancer in vivo (Hinsenkamp et al., 2016). The results found in this study using both methodologies (BrdU incorporation assay and KI-67 immunoexpression) were similar, suggesting that ROCKs proteins play an important functional role in the positive regulation of cell proliferation in OSCC.

In this study, the results suggests that signal transduction pathways involving ROCKs play an important role for the positive regulation of cell proliferation in OSCC. Although this study aimed to evaluate the involvement of ROCKs in the regulation of cell proliferation of SCC-4 cells from OSCC, with two specific inhibitors, HA-1077 and Y-27632, and two methodologies to evaluate cell proliferation, BrdU incorporation assay, and KI-67 immunoexpression, it was not possible to identify which isoform, ROCK1 and ROCK2, was responsible for the regulation of proliferation in OSCC cells, possibly ROCK2, which was identified in other types of tumours.

\section{Conclusion}

In conclusion, ROCKs proteins are attractive targets for the treatment of oral squamous cell carcinoma. The inhibitors studied is not labeled for the use in humans, future studies will be important to evaluate if the ROCKs inhibition with other therapies can lead to an inhibitory effect able to prevent completely tumourigenesis. Future studies may elucidate the effects of HA-1077 on tumor growth in animal models, leading to the possibility of conducting a clinical trial.

\section{Acknowledgments}

The authors are grateful to Fundação de Amparo à Pesquisa do Estado de Minas Gerais - FAPEMIG (APQ-01117-11) and Coordenação de Aperfeiçoamento de Pessoal de Nível Superior - CAPES for the financial support.. 


\section{References}

Abe, H., Kamai, T., Hayashi, K., Anzai, N., Shirataki, H., Mizuno, T., \& Yoshida, K. (2014). The Rho-kinase inhibitor HA-1077 suppresses proliferation/migration and induces apoptosis of urothelial cancer cells. BMC Cancer, 14, 412. https://doi.org/10.1186/1471-2407-14-412

Abraham, M. T., Kuriakose, M. A., Sacks, P. G., Yee, H., Chiriboga, L., Bearer, E. L., \& Delacure, M. D. (2001). Motility-related proteins as markers for head and neck squamous cell cancer. Laryngoscope, 111(7), 1285-1289. https://doi.org/10.1097/00005537-200107000-00027

Amano, M., Nakayama, M., \& Kaibuchi, K. (2010). Rho-kinase/ROCK: A key regulator of the cytoskeleton and cell polarity. Cytoskeleton (Hoboken), 67(9), 545-554. https://doi.org/10.1002/cm.20472

Amaya, C. N., Mitchell, D. C., \& Bryan, B. A. (2017). Rho kinase proteins display aberrant upregulation in vascular tumors and contribute to vascular tumor growth. BMC Cancer, 17(1), 485. https://doi.org/10.1186/s12885-017-3470-7

Bora, I., \& Shrivastava, N. (2017). ABCs of RhoGTPases indicating potential role as oncotargets. J Cancer Res Ther, 13(1), 2-8. https://doi.org/10.4103/09731482.204878

Breitenlechner, C., Gassel, M., Hidaka, H., Kinzel, V., Huber, R., Engh, R. A., \& Bossemeyer, D. (2003). Protein kinase A in complex with Rho-kinase inhibitors Y-27632, Fasudil, and H-1152P: structural basis of selectivity. Structure, 11(12), 1595-1607.

Chiou, S. H., Yu, C. C., Huang, C. Y., Lin, S. C., Liu, C. J., Tsai, T. H., \& Lo, J. F. (2008). Positive correlations of Oct-4 and Nanog in oral cancer stem-like cells and high-grade oral squamous cell carcinoma. Clin Cancer Res, 14(13), 4085-4095. https://doi.org/10.1158/1078-0432.CCR-07-4404

Coleman, M. L., Marshall, C. J., \& Olson, M. F. (2004). RAS and RHO GTPases in G1-phase cell-cycle regulation. Nat Rev Mol Cell Biol, 5(5), 355-366. https://doi.org/10.1038/nrm1365

David, M., Petit, D., \& Bertoglio, J. (2012). Cell cycle regulation of Rho signaling pathways. Cell Cycle, 11(16), 3003-3010. https://doi.org/10.4161/cc.21088

Defert, O., \& Boland, S. (2017). Rho kinase inhibitors: a patent review (2014 - 2016). Expert Opin Ther Pat, 27(4), 507-515. https://doi.org/10.1080/13543776.2017.1272579

Demoulin, J. B., \& Essaghir, A. (2014). PDGF receptor signaling networks in normal and cancer cells. Cytokine Growth Factor Rev, 25(3):273-83. https://doi.org/10.1016/j.cytogfr.2014.03.003

Evan, G. I., \& Vousden, K. H. (2001). Proliferation, cell cycle and apoptosis in cancer. Nature, 411(6835), 342-348. https://doi.org/10.1038/35077213

Glazer, C. A., Chang, S. S., Ha, P. K., \& Califano, J. A. (2009). Applying the molecular biology and epigenetics of head and neck cancer in everyday clinical practice. Oral Oncol, 45(4-5), 440-446. https://doi.org/10.1016/j.oraloncology.2008.05.013

Gómez del Pulgar, T., Benitah, S. A., Valerón, P. F., Espina, C., \& Lacal, J. C. (2005). Rho GTPase expression in tumourigenesis: evidence for a significant link. Bioessays, 27(6), 602-613. https://doi.org/10.1002/bies.20238

Hinsenkamp, I., Schulz, S., Roscher, M., Suhr, A. M., Meyer, B., Munteanu, B., \& Burgermeister, E. (2016). Inhibition of Rho-Associated Kinase 1/2 Attenuates Tumor Growth in Murine Gastric Cancer. Neoplasia, 18(8), 500-511. https://doi.org/10.1016/j.neo.2016.07.002

Ishizaki, T., Uehata, M., Tamechika, I., Keel, J., Nonomura, K., Maekawa, M., \& Narumiya, S. (2000). Pharmacological properties of Y-27632, a specific inhibitor of rho-associated kinases. Mol Pharmacol, 57(5), 976-983.

Jiang, L., Wen, J., \& Luo, W. (2015). Rho-associated kinase inhibitor, Y-27632, inhibits the invasion and proliferation of T24 and 5367 bladder cancer cells. Mol Med Rep, 12(5), 7526-7530. https://doi.org/10.3892/mmr.2015.4404

Johan, M. Z., \& Samuel, M. S. (2019). Rho-ROCK signaling regulates tumor-microenvironment interactions. Biochem Soc Trans, 47(1), 101-108. https://doi.org/10.1042/BST20180334

Kleer, C. G., Teknos, T. N., Islam, M., Marcus, B., Lee, J. S., Pan, Q., \& Merajver, S. D. (2006). RhoC GTPase expression as a potential marker of lymph node metastasis in squamous cell carcinomas of the head and neck. Clin Cancer Res, 12(15), 4485-4490. https://doi.org/10.1158/1078-0432.ccr-06-0376

Kümper, S., Mardakheh, F. K., McCarthy, A., Yeo, M., Stamp, G. W., Paul, A., Marshall, C. J. (2016). Rho-associated kinase (ROCK) function is essential for cell cycle progression, senescence and tumorigenesis. Elife, 5, e12994. https://doi.org/10.7554/eLife.12203

Lin, X., Khalid, S., Qureshi, M. Z., Attar, R., Yaylim, I., Ucak, I., \& Ismail, M. (2016). VEGF mediated signaling in oral cancer. Cell Mol Biol (Noisy-legrand), 62(14), 64-68. https://doi.org/10.14715/cmb/ 2016.62.14.11

Liu, B. L., Sun, K. X., Zong, Z. H., Chen, S., \& Zhao, Y. (2016). MicroRNA-372 inhibits endometrial carcinoma development by targeting the expression of the Ras homolog gene family member C (RhoC). Oncotarget, 7(6), 6649-6664. https://doi.org/10.18632/oncotarget.6544

Massano, J., Regateiro, F. S., Januário, G., \& Ferreira, A. (2006). Oral squamous cell carcinoma: review of prognostic and predictive factors. Oral Surg Oral Med Oral Pathol Oral Radiol Endod, 102(1), 67-76. https://doi.org/10.1016/j.tripleo.2005.07.038

Moreira Carboni, S. e. S., Rodrigues Lima, N. A., Pinheiro, N. M., Tavares-Murta, B. M., \& Crema, V. O. (2015). HA-1077 inhibits cell migration/invasion of oral squamous cell carcinoma. Anticancer Drugs, 26(9), 923-930. https://doi.org/10.1097/CAD.0000000000000267

Qiu, M. K., Wang, S. Q., Pan, C., Wang, Y., Quan, Z. W., Liu, Y. B., \& Ou, J. M. (2017). ROCK inhibition as a potential therapeutic target involved in apoptosis in hemangioma. Oncol Rep, 37(5), 2987-2993. https://doi.org/10.3892/or.2017.5515

Pereira, A. S. et al. (2018). Metodologia da pesquisa cientifica. UFSM. https://repositorio.ufsm.br/bitstream/handle/1/15824/Lic_Computacao_MetodologiaPesquisa-Cientifica.pdf?sequence $=1$. 
Research, Society and Development, v. 11, n. 3, e36611326730, 2022

(CC BY 4.0) | ISSN 2525-3409 | DOI: http://dx.doi.org/10.33448/rsd-v11i3.26730

Ragin, C., Liu, J. C., Jones, G., Shoyele, O., Sowunmi, B., Kennett, R., \& Taioli, E. (2016). Prevalence of HPV Infection in Racial-Ethnic Subgroups of Head and Neck Cancer Patients. Carcinogenesis, 38(2):218-229. https://doi.org/10.1093/carcin/bgw203

Steeg, P. S. (2016). Targeting metastasis. Nat Rev Cancer, 16(4), 201-218. https://doi.org/10.1038/nrc.2016.25

Stucky, A., Sedghizadeh, P. P., Mahabady, S., Chen, X., Zhang, C., Zhang, G., \& Zhong, J. F. (2017). Single-cell genomic analysis of head and neck squamous cell carcinoma. Oncotarget, 8(42):73208-73218. https://doi.org/10.18632/oncotarget.18021

Thompson, J. M., Nguyen, Q. H., Singh, M., Pavesic, M. W., Nesterenko, I., Nelson, L. J., \& Razorenova, O. V. (2017). Rho-associated kinase 1 inhibition is synthetically lethal with von Hippel-Lindau deficiency in clear cell renal cell carcinoma. Oncogene, 36(8), 1080-1089. https://doi.org/10.1038/onc.2016.272

Travassos, D. C., Fernandes, D., Massucato, E. M. S., Navarro, C. M., \& Bufalino, A. (2017). Squamous cell carcinoma antigen as a prognostic marker and its correlation with clinicopathological features in head and neck squamous cell carcinoma: Systematic review and meta-analysis. J Oral Pathol Med, 47(1):3-10. https://doi.org/10.1111/jop.12600

Vega, F. M., \& Ridley, A. J. (2008). Rho GTPases in cancer cell biology. FEBS Lett, 582(14), 2093-2101. https://doi.org/10.1016/j.febslet.2008.04.039

Wang, Z. M., Yang, D. S., Liu, J., Liu, H. B., Ye, M., \& Zhang, Y. F. (2016). ROCK inhibitor Y-27632 inhibits the growth, migration, and invasion of Tca8113 and CAL-27 cells in tongue squamous cell carcinoma. Tumour Biol, 37(3), 3757-3764. https://doi.org/10.1007/s13277-015-4115-6

Wei, L., Surma, M., Shi, S., Lambert-Cheatham, N., \& Shi, J. (2016). Novel Insights into the Roles of Rho Kinase in Cancer. Arch Immunol Ther Exp (Warsz), 64(4), 259-278. https://doi.org/10.1007/s00005-015-0382-6

Xu, X. D., Shen, H. B., Zhu, L., Lu, J. Q., Zhang, L., Luo, Z. Y., \& Wu, Y. Q. (2017). Anti-RhoC siRNAs inhibit the proliferation and invasiveness of breast cancer cells via modulating the KAI1, MMP9, and CXCR4 expression. Onco Targets Ther, 10, 1827-1834. https://doi.org/10.2147/OTT.S93164

Yang, X., Di, J., Zhang, Y., Zhang, S., Lu, J., Liu, J., \& Shi, W. (2012). The Rho-kinase inhibitor inhibits proliferation and metastasis of small cell lung cancer. Biomed Pharmacother, 66(3), 221-227. https://doi.org/10.1016/j.biopha.2011.11.011

Zhang, J., He, X., Ma, Y., Liu, Y., Shi, H., Guo, W., \& Liu, L. (2015). Overexpression of ROCK1 and ROCK2 inhibits human laryngeal squamous cell carcinoma. Int J Clin Exp Pathol, 8(1), 244-251. 